\title{
ÖLÇÜLÜLÜK İLKESİ BAĞLAMINDA KOLLUĞUN TOPLANTI VE GÖSTERİ YÜRÜYÜŞÜ HAKKINA MÜDAHALESİ: AİHM İÇTİHATLARI VE OMBUDSMAN KARARLARI ÇERÇEVESİNDE BİR ANALIZZ
}

Rıdvan Değirmenci*

\section{ÖZET}

İdarenin bugünkü uygulamalarına bakıldığında ölçülülük ilkesinin idareye belli bir ölçü getirdiği görülmektedir. Ancak söz konusu ilkenin yalın manasıyla devleti durdurmaya muktedir olmadığı görülmektedir. Zira idare kendi perspektifinden anlamlandırmaya çalıştığı problemlere odaklanmakta, bu soyut kavramın amacını çoğu zaman dikkate almamaktadır. Bu sebeple soyut ilkenin somut olayla bağlamını kurma vazifesi bağımsız kuruluşlara düşmektedir. Makalede, Avrupa İnsan Hakları Mahkemesi'nin toplantı gösteri yürüyüşü hakkını yorumlaması ve Türkiye'de yeni bir pratik olarak ortaya çıkan Kamu Denetçiliği Kurumu'nun bu konu hakkındaki kararları ölçülülük ilkesinin somutlaştııılması çerçevesinde ele alınmaktadır. Ölçülülük ilkesinin içeriğinin tüm devlet erklerince içselleştirilmesinin ne derece ehemmiyetli olduğu bu çalışmanın genelinde bir kez daha ortaya konulmak istenmektedir.

Anahtar Kelimeler: ölçülülük ilkesi, müdahaleci devlet, toplantı ve gösteri yürüyüşü hakkı, Avrupa İnsan Hakları Mahkemesi, Ombudsman.

\section{POLICE INTERFERENCE IN THE RIGHT OF ASSEMBLY AND THE RIGHT OF DEMONSTRATION WITHIN THE CONTEXT OF THE PRINCIPLE OF PROPORTIONALITY: AN ANALYSIS IN THE FRAME OF PRECEDENTS OF EUROPEAN COURT OF HUMAN RIGHTS AND DECISIONS OF OMBUDSMAN}

\begin{abstract}
Evaluating the practices of administration, it is understood that this principle tunes up to administration. But this principle is not capableof limiting the state by its pure meaning. This is because state focuses on the problems it gives meanings from its perspective and thus it usually does not take into account the aim of this abstract principle. Therefore, the mision of building a connection between this abstract principle and concrete case is assigned to independent instituations. In the article, European Court of Human Rights interpretation of freedom of assembly and demosntration and the decisions on this subject by KDK that appears as a new practice are discussed within the frame of reifying the principle of proportionality. The fact that internalization of substance of the principle of proportionality by all state bodies is very crucial is aimed to be emphasized one more time in the general context of this work.
\end{abstract}

Keywords: the principle of proportionality, interventionist state, freedom of assembly and demosntration, European Court of Human Rights, Ombudsman.

•Kamu Denetçiliği Kurumu Uzman Yardımcıs1, Ridvan.Degirmenci@ombudsman.gov.tr 


\section{GíRiş}

Temel hak ve hürriyetlerin korunması sorunu modern devletlerde siyaset bilimcilerin ve kamu hukukçularının en çok tartıştığı konulardan biridir. Bir yandan devletin merkezileşip güçlenmesi ve tüm toplumsal mekanizmaları kontrol edebilir hale gelmesi diğer yandan ise bireylerin giderek atomize olmaları bu problemi daha da sorunlu hale getirmektedir.

Hukuk, adil olanı tesis etme amacını güder. Bireysel ilişkilerde olduğu gibi devletbirey ilişkisinde de adalet hukukun rehberliğinde sağlanacaktır. Modern devlette, bireylerin adalet duygularının tatmini için gereken, devletin hukukun genel kaideleri içerisinde kalarak bireylerin özgürlüklerine müdahale etmemesidir. Ancak, modern zamanlardaki esas çelişki burada başlamaktadır. Zira, bir taraftan devletin bireyin hayatına daha az müdahalesi istenirken diğer taraftan devlet, çözüm üretmekle mükellef tutulmaktadır. Modern bireyin devlet karşısındaki büyük çelişkisini böyle özetleyebiliriz.

'Müdahaleci devletin' var olmadığı bir toplumsal sistem henüz tahayyül edilemediği ve bunun yanında bireysel refah ve huzurun devlet tarafından bozulmasının arzulanmadığı çağımızda, devletin birey hayatına ne derece müdahil olacağını belirlemek için 'ölçülülük ilkesi' bir çıkış yolu olarak belirlenmiştir. 20. yüzyılın ortalarında devlet terörü yaşanan Almanya'da akademik çevrelerce oluşturulan teori, aynı probleme gark olan diğer tüm toplumlar için bir kurtuluş reçetesi olarak addedilmiştir.

Oysa bugün ki idare uygulamalarına baktığımızda bu reçetenin yalın manasıyla devleti durdurmaya muktedir olmadığını görüyoruz. Zira idare bu soyut kavramın anlamını belirlerken kendi perspektifinden anlamlandırmaya çalıştığ sebeple soyut ilkenin somut olayla bağlamını kurma vazifesi bağımsız kuruluşlara düşmektedir. Çalışmamızda Avrupa İnsan Hakları Mahkemesi'nin toplantı gösteri yürüyüşü hakkını yorumlaması ve Türkiye'de yeni bir pratik olarak ortaya çıkan Kamu Denetçiliği Kurumu'nun bu konu hakkındaki kararlarını ölçülülük ilkesinin somutlaştırılması bağlamında ele alacağız. Ölçülü1ük ilkesinin içeriğinin tüm devlet erklerince içselleştirilmesinin ne derece ehemmiyetli olduğu bu metnin genelinde bir kez daha ortaya konulmak istenmektedir.

\section{Genel Olarak Ölçülülük İlkesi}

Temel hak ve hürriyetlerin korunması sorunu modern devletlerde siyaset bilimcilerin ve kamu hukukçularının en çok tartıştığı konulardan biridir. Zira bir taraftan bireyin hayatına devletin daha az müdahalesi istenirken bireyin iradesi daha da önemsenmekte, diğer taraftan devletin karşılaşılan sorunlara çözüm üretmesi beklenmektedir.

Hukuk, adil olanı tesis etme amacını güder. Bireysel ilişkilerde olduğu gibi devletbirey ilişkisinde de adalet hukukun rehberliğinde gerçekleştirilecektir. Modern devlette, bireylerin adalet duygularının tatmini için gereken; devletin, hukukun genel kaideleri içerisinde kalarak bireylerin özgürlüklerine müdahale etmemesidir. Ancak, modern zamanlardaki esas çelişki burada başlamaktadır. Zira, hayata müdahaleci devlet arzulanmamakta ve bireyin iradesi daha da kutsanmakta iken devlet, çözüm üretmekle 
mükellef tutulmaktadır. Modern bireyin devlete bakışındaki büyük çelişkisi böyle özetlenebilir.

Çağımızda 'müdahaleci devletin' var olmadığı bir politik sistem henüz tahayyül edilememiştir. Bununla beraber bireysel refah ve huzurun devlet tarafindan bozulmasının arzulanmadığ 1 çağımızda, devletin birey hayatına ne derece müdahil olacağını belirlemek için 'ölçülülük ilkesi' bir kılavuz olarak ortaya çıkmıştır. 20. yüzyılın ortalarında bireysel özgürlüklere çok ciddi şekilde müdahale eden devlet uygulamaları yaşanan Almanya'da akademik çevrelerce oluşturulan teori, aynı sorunun yaşandığı diğer tüm toplumlar için bir kurtuluş reçetesi olarak addedilmiştir.

Modern toplumda birey ve devlet arası ilişkiler karmaşık bir yapıya bürünmüştür. Aynı zamanda insanlar arası ilişkilerin farklı etki alanları içerisinde gerçekleşmesi ile birlikte modern dinamiklerle birey davranışlarının uyumlu hale getirilmesi gündeme gelmiştir. Burada devlet, hukuku kodifiye etme yetkisi ile bireyleri sınırlayan, dönüştüren ve topluma bir nizam veren bir kurum halini almıştır. Ancak devlet, kendisini bir üst idea olarak tasarladığında yahut birey hak ve özgürlüklerini başka kavram ve amaçlara feda edecek eğilimlere meyilli olduğunda bireylerin devlete karşı korunması gündeme gelecektir.

Ölçülülük ilkesi, temel hak ve hürriyetleri kanunla düzenleme yetkisini elinde bulunduran modern devleti sınırlandırma işlevine malik bir anayasal kurum olarak ortaya çıkmıştır. Ölçülülük ilkesi, devletin temel hak ve hürriyetleri sınırlandırırken uyması gereken temel kriterleri gösteren bir ilkedir (Metin, 2002: 19). Zira yasama organı her konuyu düzenleme yetkisine sahip olduğundan, bu tür bir sınırlandırmanın öngörülmemesi durumunda usulüne uygun olarak çıkarılan bir kanunla temel hak ve hürriyetler sinırlandırılmış olacaktır.

Modern toplumlarda temel hak ve hürriyetlerin sonuna kadar korunması istenilenin aksine bir anarşi ortamına ve bunun sonucunda bir çatışma durumuna sebebiyet verecektir. Bundan dolayı temel hak ve hürriyetlerin "olabildiğince iyi" korunması gerekliliğinden bahsedebiliriz (Rumpf, 1993: 26). Bireyin yararının kamunun yararı ile çatışma yaşaması modern dünyada kaçınılmazdır. Devletten beklenen insanın yaşamını şimdiden daha iyiye taşımasını sağlamasının yanı sıra bireyin özgürlüklerini de korumasıdır. İşte ölçülülük ilkesi devletin bu ödevleri arasındaki çatışmayı önleyecek bir ara formül olarak tasavvur edilebilecektir. Ölçülülük ilkesi devletin temel hak ve hürriyetleri sınırlandıramamasını değil, sınırlandırmasının ölçüsünü belirlediğinden siyasal karar alıcıya adeta bir rehber olmaktadır (Rumpf, 1993: 26). Aynı zamanda modern demokrasilerin temeli olan eşitlik ilkesi ile ölçülülük ilkesi arasında orantılı ve makul bir ilişki ile köprü kurulmakta ve böylelikle hür bireyler ve sağlıklı toplumsal yaşam birlikte var olabilmektedir.

Türk hukuk öğretisinde ölçülülük ilkesine ilk olarak Fazıl tarafindan yazılan Temel Hak ve Hürriyetlerinin Sınırlandırılmasının Özü adlı kitapta yer verilmiştir. Sağlam, kitabında Alman ekolünden etkilenerek ilkenin alt ilkelerini de sıralamış ve ölçülülük ilkesi öğretide bu şekliyle kabul görmüştür. Söz konusu alt ilkeler elverişlilik, gereklilik ve oranlılık olarak sıralanmıştır.

Elverişlilik ilkesi, Alman Anayasa Mahkemesi'ne göre sınırlamayı oluşturan yasal önlemin istenilen sonuca bir katkı sunması gerektiği görüşü ile tanımlanmaya çalışılmıştır 
(Sağlam, 1982: 114). Burada belirtilmek istenen; kullanılan araçla, güdülen amaca ulaşılabiliyorsa aracın elverişli, tam tersine bu durumda amaçtan uzaklaşılıyor ya da amaca ulaşmak zorlaşıyorsa aracın elverişsiz olduğudur (Metin, 2002: 26).

Gereklilik ilkesi ise; belirlenen tedbirin bu özgürlügü sınırlandırmak için makul bir tedbir olup olmadığ 1 ile ilgilidir. Yani daha farklı bir yol ile aynı amaca ulaşılabilirken daha ağır bir yol belirlendiğinde bu gereklilik ilkesi ile bağdaşmayacaktır. Sağlam'a göre bu ilke sınırlandırmanın dayandığı amacı gerçekleştirmek için en yumuşak aracın seçilmesini ifade eder (Sağlam, 1993: 115). Alman Anayasa Mahkemesi gerekliliği "amaca ulaşmada aynı etkiye sahip, bireylere daha az yükümlülük getiren başka bir araç yok ise araç gereklidir" şeklinde tanımlamıştır (Metin, 2002: 31). Görüldüğü üzere gereklilik ilkesi bireylere daha az sorumluluk yüklemek ve devleti amaca giden her yolu pervasızca kullanmaktan caydırmak amacına matuf bir ilkedir. Temel hak ve hürriyetleri sinırlandırmak isteyen devlet, bir muhakeme yaparak hangi aracın daha uygun olduğunu belirlemek ve böylelikle kendi belirlediği amaçla birey özgürlükleri arasındaki dengeyi gözetmek suretiyle bireylere sorunlu bir hayat vermekten imtina etmekle mükellef k1lınmaktadır.

Oranlılık ilkesi ise sınırlandırma ile güdülen amaç arasında bir oranının sağlanmasını amaçlar. Elverişli ve gerekli olarak tespit edilen bir tedbirin, tedbire bağlı olarak ortaya çıkan dezavantajlar ile ölçüsüz bir oran içerisinde bulunup bulunmadiğ 1 , başka bir deyişle müdahalenin ağırlığı ile gerçekleşen neticenin arasında bir orantısızlık bulunup bulunmadığ1 ve bu yüzden müdahaleden vazgeçilip geçilmeyeceği oranlılık ilkesi bağlamında değerlendirilecek hususlardır (Metin, 2002: 37). Oranlılık ilkesi göreceli bir ilkedir. Gereklilik ilkesi amaca giden araçlar arasındaki seçimle ilgili iken, oranlılık ilkesi iki değişken arasındaki ilişki ile ilgilidir (Metin, 2002: 37). Alman Anayasa Mahkemesi'nin ifadesi ile amaç ve araç birbirine karşı ölçüsüz bir oran içerisinde olmamalıdır (Sağlam, 1993: 116).

Ölçülülük ilkesi, literatürde uzun yıllar tartışılmasına rağmen pozitif anayasa metnine dahil olmamıştır. Bundan dolayı 2001 yılından önce ölçülülük ilkesinin anayasal dayanağının ne olduğu hususunda tartışmalar yaşanmıştır. Alman Anayasa Mahkemesi'nin ölçülülük ilkesini hukuk devleti ilkesinin bir gereği sayması Türk doktrininde genel olarak benimsenmiştir diyebiliriz (Sağlam, 1993: 128). Ancak Gözler bu çıkarıma karşı çıkmakta ve eğer hukuk devleti ilkesinden ölçülülük ilkesi çıkarılırsa daha pek çok ilkenin çıkarılabileceğini, bunun da hukuk devletini belirsiz kılacağını belirtmekteydi (Oğurlu, 2002: s. 40). Özbudun ise ölçülülük ilkesini Anayasa'nın 15. maddede düzenlenen temel hak ve hürriyetlerin durdurulması başlığı altındaki maddeye dayandırmaktaydı. Maddede, temel hak ve hürriyetlerin durumun gereklerine uygun olarak durdurulması gerektiği belirtilmekteydi. Özbudun, bu hükmün evleviyetle olağan zamanlardaki temel hak ve hürriyetlerin ihlaline uygulanabileceğini belirtmekte idi (Oğurlu, 2002: 41).

Anayasada yapılan 2001 yılı değişiklikleri ile 13. maddede ilke pozitif metindeki yerini almıştır. Değişiklikten önceki 13. madde genel bir sınırlandırma hükmü iken, değişiklikten sonra genel bir koruma hükmüne dönüşmüştür. Artık temel hak ve hürriyetlerin sınırlandırılmasında anayasanın sözü ve ruhu, demokratik toplum düzeninin ve laik cumhuriyetin gerekleri ve ölçülülük ilkesi üç temel düstur olarak sıralanmaktadır (Günday, 2011: 314). 
Temel hak ve hürriyetlerin sınırlandırılması bu üç düsturun rehberliğinde söz konusu olacaktır. Ancak şunu belirtmemiz gerekir ki ölçülülük ilkesi sınırlandırılabilecek temel hak ve hürriyetler için ele alınabilir. Yaşam hakkı, işkence yasağı, suç ve cezaların geriye yürümezliği gibi sert çekirdekli haklar herhangi bir sınırlandırmaya konu olamayacaklarından ölçülülük ilkesinin uygulanması söz konusu olamaz (Oğurlu, 2002: 49).

\section{2. İdare Hukukunda Ölçülülük İlkesi}

İdare hukuku ilkelerinin temel hak ve hürriyetleri doğrudan etkilediğini görmekteyiz. Özellikle idarenin işlem ve eylemlerinin yasalara uygun olduğu karinesi idarenin işlem ve eylemlerini baştan itibaren hukukî olarak nitelendirilmesini sağlamaktadır. $\mathrm{Bu}$ anlamda bireylerin temel hak ve hürriyetlerine ilişkin eylem ve işlemlerin hukukiliğinin sorgulanacağ yetkili idarî ya da adlî mercilere başvurulana dek geçen süre içerisinde bireylerin hak ve hürriyetleri ihlal edilebilecektir. Gerek idarenin ajanları gerekse idari yargı yerleri ölçülülük ilkesini göz önüne aldıklarında temel hak ve hürriyetlerin ihlalini önleyebilecektir. Atay'a göre kamu düzeni ile temel hak ve hürriyetler arasında bir çatışma söz konusudur. Devletler bu alanda tercihlerini kamu düzeninden yana kullanmaktadırlar. Ölçülülük ilkesi ve mahkemelerin bu ilkeyi uygulaması devletlerin belirtilen yetkileri kullanmasında yegâne güvence ve dengeleyici unsurdur (Atay, 2012: 616).

Modern dünyada kamu yönetimi, istikrara, hızlı karar almaya ve ilerlemeye odaklandığından temel hak ve hürriyetler uygulayıcılar tarafindan dikkate alınmayabilmektedir. Özellikle Türkiye gibi geç modernleşen ülkelerde idareyi harekete sevk eden dinamiklerin ilerleme ve gelişme kaygısını ilk planda tutması söz konusu durumu somutlaştırmaktadır. Bu durum, ölçülülük ilkesinin yalnızca kanun yapan ve onu denetleyen kurumların göz önüne alması gereken bir ilke konumundan çıkarılarak tüm adli ve idari mercilerin eylem ve işlemlerinde dikkate alacağı bir anlayışla yorumlanması ve algılanması ile önlenebilir. $\mathrm{Bu}$ manada modern ülkelerde ölçülülük ilkesi, idarenin takdir yetkisinin denetiminde önemli bir ölçü niteliği taşımaktadır (Azrak, 1993: 331). Avrupa Konseyi'nin 11 Mart 1980 tarih ve R (80)2 sayılı kararında idarenin takdir yetkisinin kullanılmasında orantılılık ilkesinin dikkate alınmasının gerekliliği vurgulanmaktadır. Bu ilke ile idareye bir sınır çizilmesinin gerekliliği belirtilmektedir denebilir (Karahanoğulları,1996: 327-333).

İdare hukukunda; kolluk ve disiplin hukuku, kamulaştırma, cebri icra gibi kurumlar ve idarenin takdir yetkisi, kamu yararı, kamu düzeni gibi temel kavramlar ölçülülük ilkesi bağlamında değerlendirilmediğinde temel hak ve hürriyetleri olumsuz etkileyebilirler (Oğurlu, 2002: 70). Özellikle idarenin işlem ve eylemlerinin icraî nitelikte olması ve kanunilik karinesinden yararlanması uygulamada büyük hak kayıplarına yol açmaktadır. İdarenin faaliyetleri, niteliğinden ötürü yasama faaliyetlerinden çok daha hızlı ve çok daha belirgin olarak insan hak ve hürriyetleri ile muhatap olmaktadır. O halde ölçülülük ilkesinin idarece ve onu denetleyen idari yargı mercilerince temel düstur olarak benimsenmesi temel hak ve hürriyetlerin korunması bakımından çok elzemdir ${ }^{1}$.

\footnotetext{
${ }^{1} \mathrm{Bu}$ hususta 1979 tarihli uluslararası anlaşma ile kabul edilen Yasa Uygulayıcılar İçin Davranıș Kurallarında yasa uygulayanların uyacağı temel kurallar benimsenmiş, ve şu şekilde sıralanmıștır: a) Yasa uygulayan görevliler ancak özel durumlarda zora başvurabilirler. b) Yasa uygulayıcıları hiçbir durumda, ulaşılacak yasal hedefle orantılı olmayan güç kullanımına yetki verir biçimde emir veremez, önlem alamaz ve davranışta bulunamaz. c) Ateşli silahların kullanılması aşırı bir önlem sayılır. Silahlı direniş ve başkalarının yaşamını tehlikeye sokma sanığın yakalanması için başkaca bir önlemin olmaması istisna olarak düzenlenmiştir ( Atasoy, 2002).
} 
İdarenin faaliyetleri çerçevesinde ölçülülük ilkesinin ele alınması gereken faaliyetlerden biri kolluk faaliyetleridir. İdari kolluk, bir ülkenin iç güvenlik, sağlık ve dirlikesenliği ile bireylerin kendilerine ve mal varlıklarına karşı olası saldırıları önlemek amacıyla idare tarafından alınan ve uygulaması da bazı yaptırımlar tarafından güçlendirilip sağlanan genel ya da birel önlemler ve bu amaca yönelik hizmetlerin hepsinin içeren bir alandır (Özay, 2002: 495). Kolluk alan1; kamu gücünün en sert biçimde gösterildiği, hak ve özgürlükleri hemen her işlem ve eylemiyle etkileme sonucu doğuran bir alandır (Oğurlu, 2002: 69).

Kamu düzeni korunurken amaç ve özgürlükler arasında dengenin gözetilmesi gerekmektedir. Bu dengelemede ne özgürlükler adına kamu düzeni göz ardı edilir ne de kamu düzeni adına özgürlükler ihlal edilir. İdarenin eylem ve işlemlerinin icrasında söz konusu özgürlüğün önemi ve ihlalin ölçüsü karşılaştırılarak bu iki unsur arasında denge kurulmalıdır (Kaya, 2014: 155). Böylelikle kolluk faaliyetlerinin gerekleri yerine getirilmiş olunurken demokratik standartlar ve özgürlükler ihlal edilmemiş olacaktır.

Kolluk faaliyetleri denetlenirken alınan önlemin haklılığı sorgulanarak kamu yararı bulunup bulunmadığı, diğer taraftan idarenin aynı sonucu daha az zorlayıcı önleme başvurarak elde etmesinin mümkün olup olmadığını denetlenmek durumundadır (Oğurlu, 2002: 72) ${ }^{2}$. Özay’a göre şayet kamu özgürlüğü hukuka uygun olarak kullanılıyor, fakat idare bunu yasaklıyorsa kolluğun aldığı önlemler hukuka aykırıdır (Özay, 2002: 510). Ancak burada hukuka uygunluğun anlamı sorgulanmalıdır. Şayet hukuka uygunluk kanuna uygunluk olarak addedilirse o zaman uygulamada birtakım sorunların önüne geçilemeyecektir. Ancak hukuk geniş manada tüm formel ve informel normlar olarak addedilirse ve bu bilinç tüm idari mercilere kazandırılırsa belli dar kalıplardan çıkılabilir ve haksız uygulamalar önlenebilir. $\mathrm{Bu}$ bakımdan kolluğun amacı yalnızca kamu düzeninin yeniden tesisi olmalıdır. Müdahale edilen alandakileri cezalandırma, yıldırma, yıpratma, itibarsızlaştırma gibi saiklerle hareket edildiğinde kolluk faaliyeti tabiî ki haksız olacaktır.

Kamu düzenini korumak için gerekli önlemlerin yetersiz olduğu durumlarda özgürlükler sınırlanabilir. Dolayısıyla önlemlerin tümü uygulandığında ve fakat kamu düzeni tesis edilemediğinde kolluk tarafından sınırlandırılmalıdır. Özay'a göre yerindelik ve ölçülülük ilkesi kolluğun faaliyetlerini sınırlayan ve denetleyen iki mekanizmadır. Yerindelik; kamunun maddi düzenini bozma tehlikesinin söz konusu olduğu durumlarda, o an için yapılması en uygun sayılan davranış biçimidir. Ölçülülük ise yerindelikle doğrudan orantılı ve ona bağlı olarak alınacak tedbirlerin sadece varılmak istenen sonuca ulaştırmaya yetecek kadarının geçerli olması anlamını taşır. Bir anlamda idarenin geniş takdir yetkisinin sinırlandırılmasıdır (Özay, 2002: s.510).

Bunun yanında ölçülülük ilkesi elverişlilik, gereklilik, oranlılık biçimindeki alt ilkeleri vasıtasıyla yerindeliğin alanına girdiği belirtilmektedir (Oğurlu, 2002: 112). Ancak idarenin denetimini etkin şekilde yapacak olan yargı erki, açıkça İdari Yargılama Usul Kanunu'nun 2. maddesi gereğince yerindelik denetimi yapamayacaktır. Bize göre temel hak ve hürriyetlerin korunması demokratik bir ülkenin olmazsa olmazıdır. Bunu ihlal eden idari faaliyetlerin tüm boyutlanyla yargı tarafından ele alınması gerekir. Bunun yerindelik denetimi gerekçesi ile önlenmeye çalışılması, mahkemelerin temel hak ve hürriyetleri koruma misyonunu zedeleyecektir. Kolluk yetkisinin sınırları Anayasa ve ilgili mevzuat olduğuna göre bu iki

\footnotetext{
${ }^{2}$ Nitekim PVSK 16. maddede düzenlenen "zor ve silah kullanma" kenar başlıklı madde kolluğun zor kullanmasını kademeli bir sisteme bağlamış ve böylelikle ölçüsüz bir müdahalenin önlenmesi amaçlanmıştır.
} 
soyut kavramı somutlaştıracak olan merci mahkemelerdir (Tan, Gözübüyük, 2010: 813-814). O halde kolluk yetkisinin sınırlarını ölçülülük ilkesi bağlamında ele alarak sınırları somutlaştıracak olan idarenin denetiminden sorumlu merciler, somut olay adaletini gerçekleştirmek ve söz konusu olaydan ilke kararları çıkarmak için idarenin takdir yetkisini ölçülülük ilkesi bağlamında değerlendirmek durumundadırlar (Yıldırım, Yasin, Kaman, Özdemir, Üstün, Tekinsoy, 2013: 563).

Ölçülülük ilkesi kanunda düzenlenmediğinden Anayasa hükmü idare tarafından doğrudan dikkate alınabilecektir. Zira İdari Yargılama Usul Kanunu'nun 2. maddesinde işlem ve eylemlerin hukuka uygunluğunun denetiminde bahsedilmektedir (Oğurlu, 2002: 97). Anayasa hukuk dahilinde olduğundan anayasa hükmü de doğrudan uygulanabilecektir. Kolluk takdir yetkisini genel sağlık, genel ahlak, kamu düzeni gibi amaçlara matuf işlem tesis ettiğinden takdir yetkisi oldukça geniştir. Takdir yetkisi sadece sebep ve konu unsuru bakımından kullanılabilir. Bu anlamda amacının kamu yararını ve kamu düzenini sağlamak olması mutlak zorunluluk olan kolluk faaliyetlerinin ölçülülük ilkesi bağlamında değerlendirilmesi kaçınılmazdır.

\section{Toplantı ve Gösteri Yürüyüşü Hakkı ve Kolluk Faaliyetleri}

Toplantı ve gösteri yürüyüşü hakkı Anayasanın 34. maddesinde:

Herkes, önceden izin almadan, silahsız ve saldırısız toplantı ve gösteri yürüyüşü düzenleme hakkına sahiptir.

Toplantı ve gösteri yürüyüşü hakkı ancak, millî güvenlik, kamu düzeni, suç işlenmesinin önlenmesi, genel sağlığın ve genel ahlâkın veya başkalarının hak ve özgürlüklerinin korunması amacıyla ve kanunla sinirlanabilir.

Toplantı ve gösteri yürüyüşü düzenleme hakkının kullanılmasında uygulanacak şekil, şart ve usuller kanunda gösterilir.

biçiminde düzenlenmiştir. Buna göre, toplantı ve gösteri yürüyüşünde izin usulü değil bildirim usulü benimsenmiştir. Anayasamızda genel sınırlandırma sebepleri kaldırıldı̆̆ından, maddede özel sınırlandırma sebepleri sıralanmış ve söz konusu hak ancak bu sebeplere binaen söz konusu sınırlanabilecektir. Son fikraya binaen 2911 sayılı Toplantı ve Gösteri Yürüyüşleri Kanunu ile bu hakkın içeriği detaylandırılmıştır.

Öncelikle 2911 sayılı Toplantı ve Gösteri Yürüyüşleri Kanununda toplantı ve gösteri yürüyüşünün amacı belirlenmiştir. Kanuna göre bu hak, halkı aydınlatmak ve kamuoyu oluşturmak suretiyle o konuyu benimsetmek amacına matuf olarak kullanılacaktır. Hakkın amacı belirlendikten sonra bildirimin nasıl yapılacağı düzenlenmiştir. Toplantıyı tertip edecek düzenleme kurulu 48 saat önceden valilik ya da kaymakamlığa toplantının yapılacağını bildirecektir. İlgili mülkî amir kanunun 6. ve 22. maddesi gereğince güzergahı belirlemek durumundadır. Burada değinmek istediğimiz husus toplantı ve gösteri yürüyüşü sırasında belirlenen yol güzergahının ihlal edilebileceği ve bu ihlalin her zaman kamu düzeni bozmayacağıdır (Kaboğlu, 2002: 413). Bu nedenle, sırf belirlenen güzergâha uyulmadığ gerekçesiyle toplantının iptali ölçülülük ilkesi ile bağdaşmayacaktır. Ayrıca, toplantının yapılmak istenildiği alana, toplananlarca bir anlam yüklenmiş olabilir. Bu durumda idarenin 
ÖLÇÜLÜLÜK İLKESİ BAĞLAMINDA KOLLUĞUN TOPLANTI VE GÖSTERİ YÜRÜYÜŞÜ HAKKINA MÜDAHALESI: AIHM IÇTIHATLARI VE OMBUDSMAN KARARLARI ÇERÇEVSINDE BİR ANALIZ

kamu düzenini gerekçe göstererek toplantıyı istenilen alanda yaptırmaması ölçülülük ilkesi ile bağdaşmayacağı kanaatindeyiz. Çünkü, kuralcı zihniyetin yasaklamada gerekçe gösterdiği kamu düzeni bu durumda daha fazla bozulmakta ve sınırlama ile varılmak istenilen amaç arasındaki dengesizlik artmaktadır.

Diğer bir husus bildirim zorunluluğunun Kanunun 3. maddesinde düzenlenmesidir. Anayasa Mahkemesine konu olan bir davada, bildirimin yedi kişiden oluşan bir tertip komitesi tarafindan yapılması şartının aranması hususunda yapılan başvurunun reddi kararına bir üye tarafından şerh düşülmüş, bu istemin Anayasa'ya aykırı olduğunu ileri sürülmüştür. Karş1 oya göre Anayasa, hakkı herkese tanırken kanunla getirilen bu şart yedi kişiden az bir topluluğun bu hakkı kullanamayacağı anlamına gelmektedir (Anayasa Mahkemesi Kararı, Esas No: 2004/90, Karar No: 2008/78, Karar Tarihi: 11/03/2008). Bize göre bu kaygı haklıdır. Çünkü Kanunda, örneğin tek kişinin gösteri yapma hakkını kullanabileceğini gösteren bir emare mevcut değildir. Hak Anayasal olduğundan Anayasa'da, hakkın kullanımı için bildirim yapılması kurucu unsur olarak belirlenmediği gözden uzak tutulmamalıdır. O halde, Kanun bildirim yükümlülügüüü bir tali unsur olarak ve kamu güvenliğini muhafaza amacı ile va'z etmiştir.

Kanunda ölçülülük ilkesi bağlamında değinilmesi gereken diğer husus 17. maddede düzenlenen yasaklama yetkisidir. Bu maddeye göre Bölge valisi, vali veya kaymakam, millî güvenlik, kamu düzeni, suç işlenmesinin önlenmesi, genel sağlığın ve genel ahlâkın veya başkalarının hak ve özgürlüklerinin korunması amacıyla belirli bir toplantıyı bir ayı aşmamak üzere erteleyebilir veya suç işleneceğine dair açık ve yakın tehlike mevcut olması hâlinde yasaklayabilir.

Kavramların muğlaklığı ve bu kavramların içeriğinin uygulamaca belirlenmesi bir yana, yaptırım olarak erteleme ve yasaklamanın öngörülmesi özgürlükçü bir bakış açısı ile ele alındığında kaygı vericidir. Burada ölçülülük ilkesinin tüm şartları değerlendirilebilir. Örneğin sadece belli kişi ve grupların toplantıya katılımının önlenmesi toplantının sıhhatli işlemesine yetecek iken kullanım hakkının ertelenmesi ve yasaklanması gereklilik unsuruna aykırı olacaktır. Yine, elverişlilik açısından ele alındığında toplantının ertelenmesi yahut yasaklanması kamu yararını gerçekleştirmeyecekse bu yaptırıma gidilmemelidir. Oranlılık ilkesi bakımından maddeyi değerlendirdiğimizde, erteleme yerine yasaklamanın yaptırım olarak öngörülmesi ölçülülük ilkesine aykırı olacaktır.

Ayrıca, yasaklanan ya da ertelenen toplantı ve gösteri yürüyüşü kararına yargı yoluna gidildiğinde, mahkeme kararını verene kadar geçecek sürede adaletin geç işlemesi söz konusu olacağı için idarenin yargı yoluna gidilmesine mahal bırakmadan kararını hukuka ve hakkaniyete uygun olarak vermesi icap eder. Ayrıca tüm bu belirlemeleri kendinde bulan ve bunu sert şekilde uygulayan idare katılanların bildirim yaptığ 1 bir merci değil, izin veren bir otoriteye dönüşecektir.

Toplantı ve gösteri yürüyüşü hakkında Kanunda, kanuna aykırı toplantı ve gösteri yürüyüşlerine geniş yer verildiği gözlemlenmektedir. Kanunun 1983 tarihinde yapıldığ1 dikkate alındığında, kanun koyucunun belleğindeki trajedilerin böyle bir düzenlemeye yol açtığını düşünmekteyiz. 12 Eylül yönetiminin kurduğu siyasal ve hukuki düzen, devletçi algılarla ve "kontrol" güdüsü ile hazırlandığından, toplum - iktidar ilişkilerini düzenleyen her kanunda bu yaklaşımın benimsendiğini görmekteyiz (Şirin, 2013: s. 30). 
Kanunun 23. maddesinde on iki farklı bentte toplantı ve gösteri yürüyüşünün kanuna aykırılığı düzenlenmiştir. Burada, kanun koyucunun muradı anayasada belirtildiği gibi herkesin bu haktan yararlanmasını sağlamak değil, devleti toplumun üzerinde ve onu kontrol eden bir mekanizma konumuna getirmektir. Ancak gelinen süreçte kanunun bu anlayıştan çıkarılarak, demokratik bir boyut kazanması sağlanamamıştır. Zira iktidarlar, toplumu ve onun dinamiklerini kontrol etmek istediğinden bu kanunun yoruma çok açık ve kontrolcü yapısından faydalanmayı bilmişlerdir.

Kanuna aykırı yürüyüşün tabirini katı yorumlandığında, atomize olmuş bireylerin birlikteliği sağladıkları nadir platformlardan olan toplanma hürriyetini gerçekleşme alanı sınırlandırılmış olmaktadır. Bu ise kitle ve iktidar arasındaki dikey ayrışmayı hızlandırmakta ve bireylerin demokrasiye katılımı yalnızca seçimlerde onaylama özgürlüklerini kullanmaktan ibaret kalmaktadir.

2911 sayılı Kanunun 24. maddesi, 23. maddede belirtilen bildirim yükümlülüğü yerine getirilmeyen, belirlenen yerlerde yapılmayan, ateşli silah ve bu gibi materyaller taşıyan kişilerin olduğu, kanunların suç saydığı maksatlar için düzenlenen ve maddede belirtilen diğer sebeplerin meydana gelmesi durumunda kanuna aykırı hale gelen toplantının nasıl sonlandırılacağını düzenlemektedir. Bu durumda toplantının kademeli olarak sonlandırılması öngörülmüştür. Öncelikle belirtmek gerekir ki 24. maddenin 4. fikrası gereği 23. maddenin b bendi kapsamında toplantının barışçıl ortamını bozan materyal kullanan kişiler o topluluktan uzaklaştırılır ve toplantının devamı sağlanır. Ancak toplantı tümüyle Kanuna aykırı hale gelirse bu durumda mülkî idare amirinin kararıyla toplantının Kanuna aykırı olduğu katılımcılara bildirilir ve dağılmaları ikaz edilir. Ancak dağılmamaları durumunda kolluk güçleri toplantıyı zor kullanarak dağıtır.

Kolluğun zor kullanma yetkisi Polis Vazife ve Salahiyetleri Kanunu'nun 16. maddesinde düzenlenmiştir. Madde metninin birinci ve ikinci fikrasında "Polis, görevini yaparken direnişle karşılaşması halinde, bu direnişi kırmak amacıyla ve kıracak ölçüde zor kullanmaya yetkilidir. Zor kullanma yetkisi kapsamında, direnmenin mahiyetine ve derecesine göre ve direnenleri etkisiz hale getirecek şekilde kademeli olarak artan nispette bedenî kuvvet, maddî güç ve kanunî şartları gerçekleştiğinde silah kullanılabilir." hükmü yer almaktadır. Buna göre polis, öncelikle ölçülü olarak kuvvet kullanmak durumundadır. Bu durumda bu kuvvetin ölçüsünün tespiti, toplu bir eyleme müdahale söz konusu olduğundan, aynı maddenin dördüncü fikrası gereği kolluk amirince tespit edilecek ve uygulanacaktır.

Görüldüğü üzere kanun koyucu kanuna aykırı bir toplantının dağıtılmasını ölçülülük ilkesi çerçevesinde düzenlemiştir. Toplantının dağıtılmasından önce ihtar etme yükümlülüğü ve buna uyulmaması durumunda kolluğun kullanacağ1 zorun ölçülü olması gerektiği kanun koyucunun muradıdır. Ancak burada temel sorun kanuna aykırılık noktasında 2911 sayılı Kanunda kullanılan kavramların muğlak oluşudur. Zira Anayasa koyucu toplantı ve gösteri yürüyüşü hakkını özgürlükçü bir bakış açısı ile düzenlerken; kanun koyucu bu hakkın kapsamını daraltmıştır. Bu durumda ilgili mercilerin kanuna aykırı saydığı hususun kolluk kuvvetlerince dağıtılması hiyerarşi çerçevesinde zaruridir. Diğer bir husus ise, kolluğun güç kullanımının kademeli olarak düzenlenmesine karşın bu kademeli müdahalenin kapsamı noktasında kolluk personelinin ve amirlerinin tutumlarıdır. Çalışmamızın kapsamında kararlarını ele alacağımız Avrupa İnsan Hakları Mahkemesi ve Kamu Denetçiliği Kurumu bu iki probleme dikkat çekmekte, kanun koyucunun yasakçı tavrının değişmemesini ve kolluğun toplantının dağıtılması esnasında ölçüsüz müdahalesini eleştirmektedir. 


\section{Avrupa İnsan Hakları Mahkemesi Kararlarında Toplantı ve Gösteri Yürüyüşü Hakkı}

Avrupa İnsan Hakları Sözleşmesi'nin 11. maddesinde toplantı ve gösteri yürüyüşü hakkı "Herkes barışçıl olarak toplanma ve dernek kurma hakkına sahiptir. Bu hak, çıkarlarını korumak amacıyla başkalarıla birlikte sendikalar kurma ve sendikalara üye olma hakkını da içerir." şeklinde düzenlenmiştir. Toplanma ve dernek kurma hakkının bir arada düzenlenmesinden muradın, her iki hakkın bireylerin demokratik tepkilerini duyurabilecekleri toplumsal platformları oluşturmak olduğu anlaşılmaktadır. Düzenlemede hiçbir şart öngörülmeksizin barışçıl bir ortamda bu haktan faydalanmaları öngörülmüştür. Zira AİHM kamu düzeninin gerekleri ile sözleşmede koruma altına alınan haklar arasında adil bir denge gözetmektedir. Ancak AİHM nezdinde kamu düzeni-özgürlük arasında özgürlük daha fazla korunmaya değer bulunmaktadır (Tekinsoy, 2011: 298).

AİHM, toplantı hakkını demokratik toplumun temel niteliklerinden biri olarak nitelendirdiğinden dar yorumlanmaması gerektiğini ifade etmektedir. "Barışçıl toplantı ve gösteri yürüyüşü hakkı demokratik bir toplumda temel haklardan biridir. Aynı ifade özgürlüğ̈̈ gibi, [bu hak da]demokratik toplumun temellerinden birini teşkil etmektedir. İste bu sebeple bu hak dar yoruma tabi tutulmamalıdır." içtihadı AİHM'in temel mottosudur (Tanyar, 2011: 599).

AİHM barışçıl toplanma özgürlüğü kapsamında yürüyüşleri, gösterileri, oturma eylemlerini, halka açık toplantılar gibi diğer ifade çeşitlerini sınırlanmaksızın madde kapsamında değerlendirmektedir (Harris, O’Boyle, Bates, Buckley, 2013: 532). Bu bağlamda hakkın sözleşmenin koruması kapsamına alınması için aranan tek kıstas toplanmanın 'barışçıl' olmasıdır. Bu bağlamda toplantıya katılanlar içerisinde şiddet eğilimli kişilerin olmasını AİHM hakkın ihlali kapsamında değerlendirmemektedir. AİHM şiddete başvurulmadığı sürece hoşgörünün gösterilmesi gerektiğini vurgulamıştır" . "(Nurettin Aldemir ve Diğerleri/ Türkiye (no. 32124/02, 32126/02, 32129/02, 32132/02, 32133/02, $32137 / 02$ ve 32138/02) sendika üyesi olan 8 başvurucunun 2001 y1lında yeni çıkacak bir yasayı protesto etmek için Ankara'da düzenledikleri gösterilere polis tarafından müdahale edilmesi ile ilgili yaptıkları başvuruda Mahkeme polis tarafindan müdahalenin yasalarca öngörülmüş olmasına ve meşru bir amaca dayanmasına karşın toplantı ve gösteri hakkının barışçıl şekilde kullanıldığı durumlarda kamu makamlarının belli oranda hoşgörülü olması gerektiğini ve müdahalenin orantılı kabul edilmeyeceğini belirterek 11. maddenin ihlal edildiğine karar vermiştir. Saya ve diğerleri davasında "Mahkeme’nin görüşüne göre göstericiler şiddet içermeyen eylemlerde bulunuyorlarsa, Sözleşme'nin 11.maddesi tarafindan garanti altına alınan toplanma özgürlüğünün tüm esasından yoksun kalınmaması amacıla kamu makamlarının barışçıl toplantılara bir dereceye kadar tolerans göstermeleri önemlidir." denilerek devletin vatandaşların sarsıcı söylemlerine müdahale etmesini gereksiz ve orantısız bulmuştur. Toplumu sarsacak derecede radikal ifade biçimlerinin dile getirilmesini şiddet kapsamında değerlendirmeyen AİHM, bu tarz ifadelerin toplant1 özgürlüğünün doğasında var olduğunu ifade etmektedir. Ezelin-Fransa davasında mahkeme toplantı esnasında yer yer şiddet olaylarının baş göstermesini şiddet eylemine katılmayan bireylerin söz konusu hakkını kullanmalarına mani olunmasını gerektirecek bir sebep olarak görmemiştir (Doğru, Nalbant, 2013: 432.).

\footnotetext{
${ }^{3}$ Biçici ve Türkiye Kararında Mahkeme benzer gerekçeyle ihlal kararı vermiştir. Yine Mahkeme şiddete başvurulmadığından Öcalan'ın desteklendiği gösteriyi makul görmektedir (Turan Biçer ve Türkiye).
} 
AİHM hakkın yorumlanmasında devletlere pozitif bir yükümlülük yüklemektedir. Bu yükümlülük devletin toplantıya katılanların karşıt göstericilerin şiddet içerikli tacizlerinden korumasıdır. Buna göre bir toplantıya karşı karşıt görüş taşıyan bireyler toplantı düzenler ise bu durumda devletin görevi her iki grubun haklarını korumaktır. Ancak gruplardan biri şiddet hareketlerine girişirse devlet, diğer grubun zarar görmemesi için gerekli tedbirleri almakla mükelleftir (Doğru, Nalbant, 2013: 435). 11. maddenin asıl amacı, kişiyi yetkili makamların korunan haklarının uygulanmasına keyfi olarak müdahale etmekten koruması olmasına rağmen, AİHM bu madde kapsamında söz konusu hakların etkin şekilde kullanılmasını temin edecek pozitif yükümlülüklerin de mevcut olabildiği kanısındadır. AİHM, devletlerin sadece toplantı yapma hakkını korumakla kalmayıp, bu hakkı dolaylı yoldan usulsüz bir şekilde sınırlandırmaktan da kaçınmalarının gerektiğini hatırlatmaktadır. Diğer taraftan AİHM, 11. maddenin esasen kamu güçlerinin, bireyin güvence altına alınan haklarına keyfi müdahalesine karşı korumayı amaçlamakla birlikte, fazladan bu hakların etkili bir şekilde kullanılmasını sağlamak için pozitif yükümlülük de getirebileceğini kaydetmektedir. Türkiye hakkında vermiş olduğu ihlal kararında mahkeme bu hususu değerlendirmiş ve , "Devletlerin yalnızca barışçı yöntemlerle toplanma özgürlüğ̈̈nü güvence altına almakla yükümlü olmadı̆̆ını, aynı zamanda bu hakka dolayl yoldan getirilecek aşırı kısıtlamalardan da kaçınmaları gerektiğini hatırlatmaktadır. Ayrıca 11. madde esasen kamu erkinin, bireyin güvence altına alınan haklarına keyfi müdahalesine karşı korumayı amaçlamakla birlikte, ayrıca bu hakların etkili bir sekilde kullanılması için pozitif yükümlülük de getirmektedir." diyerek bu yükümlülüğü hatırlatmıştır (Gülizar Tuncer/ Türkiye Davası).

Hakkın kullanılmasında diğer bir önemli husus ise barışçıl toplanma hakkına yönelik müdahalelerdir. AİHS' in 11. maddesinin 2. fikrasinda "Bu hakların kullanılması, yasayla öngörülen ve demokratik bir toplum içinde ulusal güvenliğin, kamu güvenliğinin korunmasl, kamu düzeninin sağlanması ve suç işlenmesinin önlenmesi, să̆lı̆̆ın veya ahlakın veya başkalarının hak ve özgürlüklerinin korunması için gerekli olanlar dışındaki sınırlamalara tabi tutulamaz. Bu madde, silahl kuvvetler, kolluk kuvvetleri veya devlet idaresi mensuplarınca yukarda anılan haklarını kullanılmasına meşru sınırlamalar getirilmesine engel değildir." denmektedir. Mahkeme toplantıya müdahalenin hakkın ihlalini gerektirip gerektirmediğini üçlü test olarak bilinen üç temel unsur kapsaminda değerlendirerek tespit etmektedir (Harris, O’Boyle, Bates, Buckley, 2013: 537). Buna göre mahkeme müdahalenin kanunî düzenlemeye dayanması, meşru amaç taşıması ve demokratik toplum gereklerine uygun olması yönünden değerlendirmektedir (Oya Ataman/Türkiye). Bu bağlamda mahkeme toplantı özgürlügüünü önceden izin ya da bildirim yükümlülügüne bağlanmasını hakkın ihlali olarak görmemektedir (Harris, O’Boyle, Bates, Buckley, 2013: 536). Ancak sirf bildirim yükümlülüğünün yerine getirilmediği gerekçesiyle toplantı hakkına müdahaleyi meşru görmemektedir. Oya Atman v. Türkiye davasında devletin iç mevzuatında toplantı ve gösteri yürüyüşü hakkı için gerekli tedbirleri alması makul görülürken, göstericilerin demokratik haklarını kullanmamalarının sırf bildirim yükümlülüğüne aykırı olması hasebiyle kullandırılmamasını doğru bulunmamıştır (Oya Ataman/Türkiye). İlgili konu başlığında belirttiğimiz gibi bildirim kuralının sıkı sıkıya uygulanması hak ihlallerini doğuracaktır. Temel hak olan toplanma hakkını ihlal edecektir, dolayısıyla uygulayıcıların ve kanun koyucunun bu katı tutumlarından bir an evvel vazgeçmeleri gerekmektedir.

AİHM, önceden bildirim yapılmasının gerekliliğini kabul etmektedir. Sonuçta kamuya açık alanda yapılan bir yürüyüş toplumun genelini etkileyecektir. Ancak barışçıl amaçlarla başlamış bir gösterinin sırf izin alınmadığı gerekçesiyle kişilerin cezalandırılmasını hukuka aykırı görmektedir. AİHM, "başvuranlar hakkında sırf izinsiz ama barışçıl bir gösteriye 
ÖLÇÜLÜLÜK İLKESİ BAĞLAMINDA KOLLUĞUN TOPLANTI VE GÖSTERİ YÜRÜYÜŞÜ HAKKINA MÜDAHALESİ: AIHM İÇTIHATLARI VE OMBUDSMAN KARARLARI ÇERÇEVSINDE BİR ANALIZZ

katılmalarından ötürü dava açılmasından - ve ilk derece mahkemesinde mahkum edilmelerinden - endişe duymaktadır. Barışçı bir gösterinin, ilke olarak, cezai yaptırım tehdidine maruz bırakılmaması gerekir" demektedir ( Akgöl/Göl ve Türkiye). Yine başka bir davada mahkeme kişilerin İstiklal Caddesinde önceden bildirmeden toplanmalarının iç hukukta 2911 sayılı Kanunun 22. maddesi kapsamında müdahale gerekçesi olarak düzenlendiğini belirtse de polisin göstericileri dağıtmak için kaba kuvvet kullanmasını ve haklarında ceza yargılamasının başlatılmasını orantısız bulmuştur (Serkan Yılmaz ve Diğerleri/ Türkiye).

AİHM'in 11. madde kapsamında Türkiye aleyhine vermiş olduğu ihlal kararları genel olarak kolluğun sert müdahalesine ve toplantı ve gösteri yürüyüşünün şiddet içermemesine rağmen 2911 sayılı Kanun gereğince cezaî yaptırıma tabi tutulması hakkındadır. Mahkeme önüne gelen dosya kapsamında protestocuların salondan çıkarılması akademik toplantının selameti açısından yeterli iken, öğrencilerin darp edilmesi ve göz altına alınması toplantı ve gösteri yürüyüşü hakkını ihlal eden orantısız güç uygulamaları olarak nitelendirilmiştir. $\mathrm{Bu}$ kararda görüldüğü üzere, kolluk ölçülülük ilkesini benimsemiş olsa idi ve eylemle amaç arasında bir oranlılık arasa idi ihlal kararına yer olmayacaktı (Açık ve Diğerleri/ Türkiye). AİHM bir başka kararında tedbirlerin kanunî ve meşru bir amaç gütmesini kabul etmekle beraber, toplantıya katılanların basın açıklaması yapmalarına engel olmanın ve ceza davasının açılmasının demokratik toplum gereklerine aykırı olduğu kanısındadır (Aşıc1/Türkiye).

Mahkeme kolluğun gösterilere müdahalesinin oransızlığının yanı sıra 2911 sayılı Kanun çerçevesinde kanuna aykırı olarak düzenlenen ve cezaî yaptırıma bağlanan eylemler nedeniyle katılımcılara ceza davasının açılmasını ihlal sebebi olarak görmektedir. Akgöl ve Göl, Pekaslan, Gün ve Diğerleri/ Türkiye davalarında mahkeme barışçıl olan gösteri yürüyüşüne müdahaleyi ve katılımcılara ceza davası açılmasını gereksiz ve orantısız bulmuştur.

Son tahlilde AİHM toplantı ve gösteri yürüyüşü hakkının kapsamını oldukça geniş tutmakta ve devletlere bu hakkın sınırlandırılması ve hakka müdahale hususunda ölçülü davranmalarını tavsiye etmektedir. Mahkeme için hakkın sınırlandırılabileceği temel ölçüt 'barışçıl' vasfını yitirmedir. Eğer gösteri şiddet yahut şiddete teşvik içermiyorsa müdahale etmek demokratik toplum gereklerine aykırı olacaktır. Devletin bu noktada hoşgörülü olma ve hakkın kullanılabilmesi için gerekli önlemleri alma yükümlülüğü olduğunu hatırlatan mahkeme bu yükümlülüğü yerine getirmek yerine devlet tarafindan gösteriye müdahale edilmesini ihlal sebebi saymaktadır. Ayrıca Mahkeme, 2911 sayılı Kanun kapsamında sayılan kanuna aykırı gösteri toplantı ve gösteri yürüyüşü sebeplerini ve bu sebeplere dayanılarak yapılan müdahaleleri sözleşmeye aykırı görmektedir. AİHM bu noktada hem kolluğun ölçüsüz müdahalesini hem de bu müdahaleye sebep olan kanunları kendi bakış açısı çerçevesinde ölçülü bulmamaktadır.

\section{Kamu Denetçiliği Kurumu'nun Toplantı ve Gösteri Yürüyüşü Hakkında Vermiş Olduğu Tavsiye Kararları}

Kamu Denetçiliği Kurumu 2012 yılında kurulmuş ve 2013 yılının Mart ayından itibaren şikayetleri alarak görevini ifa etmeye başlayan bir kamu kurumudur. Henüz kuruluş aşamasında Türkiye'nin içinden geçtiği sancılı süreçte toplumsal olaylarda devletin müdahalesi hakkında kendisine yapılan başvurulara kayıtsız kalmamış ve kamuoyunda 'Gezi 
Eylemleri' olarak bilinen olaylar silsilesi hakkında genel bir çalışma yaparak, bu olaylar içerisinde polisin gösterilere müdahalesi sırasında yaralanan bir vatandaş hakkında yapılan başvuruyu değerlendirerek tavsiye kararı vermiş ve toplantı ve gösteri yürüyüşü hakkında temel içtihatlarını ortaya koymuştur.

Kurumun şikayetleri alma tarihi olan 2013 yılının Mart ayının ertesinde 1 Mayıs Emek ve Dayanışma Günü etkinlikleri kapsamında idarece alınan tedbirler şikayet konusu yapılmıştır. Söz konusu başvuruda İstanbul Valiliği'nin 1 Mayıs Emek ve Dayanışma Günü dolayısıyla yasa dışı gösterileri önlemek amacıyla İstanbul'da ulaşım seferlerinin iptal edilmesi şikayet konusu yapılmıştır. Şikayet konusuna ilişkin incelemelerini tamamlayan Kamu Başdenetçisi İstanbul Valiliği ve İçişleri Bakanlığı tarafından Taksim Meydanı'nın devam eden inşaat çalışmaları sebebiyle kutlamalara kapatılmasını hukuka uygun bulmuştur. Ancak şikayet konusu olan seyahat özgürlügünün Taksim Meydanı'nda uygulanan tedbirin gereği olarak sınırlandırılmasının güvenlik gerekçesi ile aşırı şekilde sınırlandırılmasını Kamu Başdenetçisi hakkaniyete aykırı bulmuştur. Kamu Başdenetçisi, söz konusu seyahat özgürlüğü sınırlandırılmasının anayasanın sözüne ve ruhuna aykırı olduğunu dile getirmiş, bu sınırlamanın yaşanan olayların gerektirdiği makul ölçekten daha fazla kısıntıya uğrattığı ve bu durumun hakkaniyete aykırı olduğunu tespit etmiştir (KDK Tavsiye Kararı, Karar No: 2013/33). Bu noktada 'makul ölçek' kavramına yer veren Kamu Başdenetçisi, güvenlik gerekçesi ile kolluğun faaliyetlerinin mühim olduğunu vurgulamış ancak söz konusu kavramı merkeze alarak bu faaliyetlerin 'insan hakları' ve 'insan onuru'na layık şekilde örgütlenmesinin ve uygulanmasının gerekliliğini vurgulamıştır. Bu gerekçelerle İstanbul Valiliği'ne hatalı davranıldığının kabulü ve şikayet konusu uygulamaların tekrarlanmasının önlenmesi için gerekli tedbirlerin alınması hususunda 'Tavsiye Kararı'nda bulunmuştur (KDK Tavsiye Kararı, Karar No: 2013/33).

Bir başka kararında Kamu Başdenetçisi, 1 Mayıs Emek ve Dayanışma Günü kapsamında yasadışı gösteri yapan gruba karşı polisin müdahalesi neticesinde ağır yaralanan çocukla alakalı yapılan şikayeti değerlendirmiştir. Bu noktada öncelikle uluslararası ve ulusal mevzuatı ele alan Kamu Başdenetçisi uluslararası yargısal ve diğer mercilerin şikayet konusuna ilişkin kararlarını sıralamış, Türk yargısının konuyla alakalı bakışını kararına derç etmiştir. Akabinde, şikayet konusunu hukuka uygunluk yönünden üç başlık altında değerlendirmeye tabi tutmuştur; kolluk kuvvetlerinin güç kullanımı, toplantı ve gösteri yürüyüşü hakkı ve çocuk hakları. Bu noktada Kamu Başdenetçi kolluğun uyarı yapmaksızın sert müdahalede bulunmasını, bu müdahale sonunda bir çocuğun ağır biçimde yaralanmasını ölçüsüz ve orantısız bulmuş, hukuka aykırı görmüştür. Yine toplantı ve gösteri yürüyüşü hakkı kapsamındaki değerlendirmesinde, şikayete ilişkin olayların vuku bulması sırasında şikayetçilerin şiddete başvuran kişiler arasında olmasına rağmen şiddet eylemi gösterdiklerine dair bir emarenin bulunmadığı dile getirilmiş, kolluğun anayasal hak olan toplantı ve gösteri yürüyüşü hakkının vatandaşların kullanmasını sağlamakla yükümlü olduğunu hatırlatılmış, şiddete başvuran kişiler ile başvurmayanlar arasında bir ayrım yapılmaksızın başvurulan müdahaleyi özgürlüklerin ihlali olarak yorumlamıştır. Müdahale kapsamında yaralanan kişinin çocuk olması sebebiyle Kamu Başdenetçisi, müdahale sonucu meydana gelen ağır yaralanma sebebiyle uluslararası ve ulusal mevzuata aykırılık durumu oluştuğunu beyan etmiştir. Sonuç olarak şikayet konusu toplumsal olaylara müdahale eden kolluk personelinin müdahalesini ölçüsüz bulan Kamu Başdenetçisi, kolluğun müdahale esnasında uluslararası sözleşmelerde koruma altına alınan hakları ihlal etmemesi için orantılı güç kullanması gerektiğini, bu hususta sürekli eğitime tabi tutulmalarının zarurî olduğunu, kolluk görevlilerinin toplumsal olaylarda müdahalesinin etkin bir inceleme ve soruşturmaya tabi 
ÖLÇÜLÜLÜK İLKESİ BAĞLAMINDA KOLLUĞUN TOPLANTI VE GÖSTERİ YÜRÜYÜŞÜ HAKKINA MÜDAHALESI: AİHM İÇTIHATLARI VE OMBUDSMAN KARARLARI ÇERÇEVSINDE BİR ANALİZ

tutulması gerektiğini dile getirmiştir. Ayrıca kolluğun müdahalesinde güç kullanımının ve biber gazı kullanımının mevzuatta açık, net, öngörülebilir şekilde düzenlenmesi gerektiğini vurgulamıştır ( KDK Tavsiye Kararı, Karar No: 2013/69)

Gezi olaylarına ilişkin hazırlamış olduğu kapsamlı raporunda birçok konuya temas eden Kamu Başdenetçisi, toplantı ve gösteri yürüyüşü hakkının kullanılması ve bu hakkın kullanılmasının sınırlandırılmasına ilişkin temel görüşlerini ortaya koymuştur. Çok boyutlu olaylar silsilesini değerlendirdikten sonra Kamu Başdenetçisi, ifade ve toplanma özgürlüklerini düzenleyen ulusal mevzuatın lafzî yorumlanmasının neticesinde söz konusu hakların sınırlandırmanın sınırını aşacağını ifade etmiş, mevzuatın ulusal ve uluslararası standartlar çerçevesinde tekrar gözden geçirilmesini tavsiye etmiştir (KDK Tavsiye Kararı, Karar No: 2013/90). Bunun yanı sıra Kamu Başdenetçisi özellikle kolluğun gösteriler esnasında yer yer sert müdahalesine şahit olunduğunu, toplumsal olaylara müdahale noktasında mevcut politikaların gözden geçirilmesi gerektiğini bu çerçevede güvenlik kaygılarını ortadan kaldırırken özgürlükçü ve birey çerçeveli bakış açısını ihmal etmeyen bir politikanın belirlenmesi gerektiğini ifade etmiştir (KDK Tavsiye Kararı, Karar No: 2013/90). Kamu Başdenetçisi ayrıca kolluğun toplantı ve gösteri yürüyüşüne müdahale etmesi hususuna ilişkin değerlendirmelerde bulunmuş; kolluğun zor kullanma araçlarının öldürücü ve öldürücü olmayan şeklinde tekrar belirlenmesi, müdahale kararının daha soğukkanlı bir mekanizma tarafından alınması, müdahale sırasında yaralananlara tıbbî yardımın daha kurumsal hale getirilmesi, müdahaleye ilişkin raporlamanın geliştirilmesi, toplumsal olaylara müdahale eden kolluk personelinin hizmet öncesi ve hizmet içi eğitiminin tekrar düzenlenmesi, toplumsal olaylara müdahalede sertifikalı personelin kullanılması, söz konusu personelin, mülkî amirlerin ve savcıların toplumsal katmanlarla iletişim, kitle psikolojisi, müzakere anlayışı, ikna gücü konularında eğitime tabi tutulmaları hususlarını tavsiye kararında belirtmiştir (KDK Tavsiye Kararı, Karar No: 2013/90). Kurumun tavsiye kararın İzci ve Türkiye davasında belirtilen hususlarla paralellik arz ettiği görülmektedir. AİHM kararında göz yaşartıcı gazın kullanımına ilişkin hususların düzenlenmesi, kolluk personelin bu yönde eğitilmeleri, kontrol ve gözetimin artırılması, ayrıca sert direniş göstermeyen kişilere karsı güç kullanımının gerekli, orantılı ve makul olup olmadığına ilişkin olarak, olayın gerçekleşmesinden sonra etkin bir inceleme yapılmasının son derece önemli olduğunu belirtmiştir (İzci/Türkiye). KDK'nın Gezi Olayları ile alakalı hazırlamış olduğu raporun AİHM'in söz konusu kararı ile örtüşmesi somut olayları değerlendirme kriterlerinin benzeştiğini göstermektedir.

Kamu Denetçiliği Kurumu 6328 sayılı Kanun'un 1. maddesinde belirtildiği üzere idarenin her türlü eylem ve işlemini, tutum ve davranışını insan haklarına dayalı adalet anlayışı içinde hukuka ve hakkaniyete uygunluk yönünden değerlendirmek ve tavsiyelerde buılunmakla görevlidir. Çalışmanın konusu mucibince vermiş olduğu kararlarında KDK, bireylerin idare ile karşı karşıya geldiği toplantı ve gösteri yürüyüşü hakkının kullanılmasına ilişkin uluslararası mevzuat ve insan hakları anlayışı çerçevesinde hareket etmiştir. $\mathrm{Bu}$ noktada ulusal mevzuatın yetersiz kaldığını, değiştirilmesi gerektiği görüşündedir( KDK Tavsiye Kararı, Karar No: 2013/90). Bu noktada KDK uluslararası standartları özümseyen yaklaşımı ile genelde idarenin özelde kolluk güçlerinin toplantı ve gösterilere müdahalesini insan hakları perskpektifinden değerlendirmektedir. Kurum AİHM'in belirlediği standartlara ek olarak devlete somut öneriler getirmektedir. Bu noktada ölçülülük ilkesinin alt ilkeleri olan elverişlilik, gereklilik ve oranlılık ilkesinin somut olayın bileşenleri ile bütünleştirilmesi noktasında idareye ön açan, yol gösteren önerilerde bulunmaktadır. İdare hukukunda yeni kabul gören ölçülülük ilkesinin somutlaştırılmasında Kurumun bakış açısının doğru 
temellenmesi ve örneklerde görüldüğü üzere teori ve pratiği bütünleştirebilmesi kolluğun müdahalelerinin ölçülülük ilkesine uygunluğunu sağlama noktasında idareye imkan sunabilecektir.

\section{SONUÇ}

Ölçülülük ilkesi Türk doktrininde yeni tartışılmaya başlanan bir kavramdır. 2001 yılında Anayasa metnine dahil edilmesi ile hakkında yapılan tartışmalar anayasa hukuku tekelinden çıkarak idare hukuku alanına sirayet etmiştir. Gerek idarenin kararlarını almada ve uygulamadaki pratikliği gerekse bireyle olan fiziksel temasının yoğunluğu sebebi ile bu ilkenin idare hukuku bağlamında tartışılmasını elzem kılmaktadır.

Bu çalışmada, idare hukukunun bir konusu olan kolluk faaliyetleri ve anayasal bir hak olan toplantı ve gösteri yürüyüşü hakkını birlikte değerlendirildi. Kanunî düzenlemede kolluğa bu hakkı sınırlandırmak için birçok yetki verildiğini gözlemledikten sonra bu yetkilerin uygulamada yaşattığı sıkıntılara değinmeye çalışıldı. Başta da belirtildiği gibi, atomize olmuş bireylerin meşru taleplerini iktidara iletebilecekleri ender seçeneklerden biri olan toplantı ve gösteri yürüyüşü hakkının idare tarafından yorumlanması oldukça önemlidir. Çağımız enformasyon çağı olduğu kadar toplumsal algıların yönetildiği bir çağdır. Bireylerin sivil toplumda özgürce örgütlenebilmeleri kamuoyunun maniple edilmesini önler. Bundan ötürü çeşitli platformlarda örgütlenmek, demokratik kültürün gelişmesini ve bireylerin özgür hareket etmelerini sağlayacaktır.

Ancak iktidarlar, bu durumda politikalarını halka daha zor kabul ettireceklerinden yahut icraatlarının ardından daha profesyonel ve organize tepkiler alacağından yukarıda bahsedilen portreyi istemeyebilirler. Bunu önlemek için ise çeşitli argümanlar kullanırlar. Yasalar, kararlar, idari işlemler sayesinde bu durumu lehlerine olacak düzeye getirebilirler. İşte Avrupa İnsan Hakları Mahkemesi, iktidar doğasını dikkate alarak özgürlüklerin en geniş şekli ile yorumlanması gerektiği ve muğlak ifadelerle özgürlüklerin kısıtlanmaması gerektiğini kararlarında vurgulamaktadır.

12 Eylül 2010 referandumu ile anayasal bir kurum olarak düzenlenen ve 2012 y1lında kurulan Kamu Denetçiliği Kurumu (Ombudsman), 2013 yılından itibaren şikayet başvurularını almaya başlamıştır. Kuruluşundan itibaren geniş halk kitlelerinin katıldığ gösteri ve yürüyüşler ülke genelinde vuku bulmuştur. Bu toplantılarda kolluğun ölçüsüz güç kullandığına ilişkin şikayetleri inceleyen Kamu Denetçiliği Kurumu, toplantı ve gösteri yürüyüşü hakkını AİHM'in içtihatları çerçevesinde değerlendirmiştir. Bu durumda esas olarak kolluğun gösterilere müdahalesini AİHM çerçevesinde değerlendirmiş, bu müdahaleye zemin hazırlayan kanunî metinlerin günün şartlarına ve demokratik toplum kriterlerine uygun olmadığını belirtmiştir. Bunun yanı sıra kolluğun eylemlere müdahalesinin sebep ve sonuçlarını irdeleyen Kurum, bu bağlamda idareye kolluğun eğitimi, kamu otoritesinin ve yarg1 mercilerinin gösteriler karşısında nasıl bir tutum takınması gerektiğini göstermeye çalışmıştır. 
Ölçülülük ilkesi demokratik bir toplumda iktidar ve bireyin karşı karşıya geldiği anlarda iktidarın birey özgürlüklerine müdahalesinin sınırlarını belirleyen temel bir ilkedir. Ancak bu ilkenin toplantı ve gösteri yürüyüşü hakkına müdahalenin somutlaştırılması noktasında sorunlar oluşabilmektedir. Dolayısıyla AİHM'in bu noktada içtihatlarının ülkelere rehber olması idarenin keyfiliğini ve hakkın özünün korunması açısından elzemdir. Bununla beraber yerel kurumların bu ilkeyi ülkenin somut şartlarına uygun olarak değerlendirmesi ve iktidarlara yol göstermesi demokratik toplumun dinamiklerinin oluşması ve iyi yönetişim açısından kilit rol oynamaktadır. Kamu Denetçiliği Kurumu hassas toplumsal olaylarda idarenin müdahalesinin sınırlarını somutlaştırarak ölçülülük ilkesinin soyut bir tasavvurdan çıkararak somut bir norma dönüşmesi hususunda çaba göstermektedir. 


\section{KAYNAKÇA}

\section{Kitap/Makale}

ATASOY, Ömer Adil (2002). Temel Hak ve Hürriyetlerin Sınırlandırılmasında Yeni Bir Kavram: Ölçülülük İlkesi ve Yasa Uygulayıcılar Açısından Uyma Zorunluluğu, Anayasa Yargısı Dergisi, Cilt No: 19,

ATAY, Ender Ethem (2012). İdare Hukuku, Seçkin Yayınları, Ankara.

AZRAK, Ali Ülkü (1993). İdari Yargı Kararlarında Anayasaya Uygunluk Sorunu, Anayasa Yargısı Dergisi, Cilt 9, Ankara.

DOĞRU, Osman, Atilla Nalbant (2013). İnsan Hakları Avrupa Sözleşmesi, Pozitif Matbaa, Ankara.

GÖZLER, Kemal (2009). İdare Hukuku Cilt 2, Ekin Kitabevi, Bursa.

GÜNDAY, Metin (2011). İdare Hukuku, İmaj Yayınevi, Ankara.

HARRİS, David, O’Boyle, Michael, Bates, Ed, Buckley, Carla (2013). Avrupa İnsan Hakları Sözleşmesi Hukuku, Şen Matbaa, Ankara.

KARAHANOĞULLARI, Onur (1996). İdari Takdir Yetkisinin Kullanılmasın İlişkin R(80)2 Sayılı Avrupa Konseyi Bakanlar Komitesi Tavsiye Kararı, Ankara Üniversitesi Hukuk Fakültesi Dergisi, Cilt 45, Sayı 1-4.

KABOĞLU, İbrahim (2002). Özgürlükler Hukuku, İmge Kitabevi, Ankara.

KABOĞLU, İbrahim (2005). Anayasa Hukuku Dersleri, Legal Yayıncılık, İstanbul.

KAYA, Cemil (2014). İdarenin Takdir Yetkisi ve Yargısal Denetimi, XII Levha Yayıncılik, İstanbul.

METİN, Yüksel (2002). Ölçülülük İlkesi, Seçkin Yayınları, Ankara.

OĞURLU, Yücel (2002). Karşılaştırmalı İdare Hukukunda Ölçülülük İlkesi, Seçkin Yayınları, Ankara.

ÖZAY, İlhan (2002). Gün Işı̆̆ında Yönetim, Alfa Yayınları, İstanbul.

RUMPF, Cristian (1993). Ölçülülük İlkesinin Anayasa Yargısındaki İşlevi ve Niteliği, Anayasa Yargısı Dergisi, Cilt No: 10. 
ÖLÇÜLÜLÜK İLKESI BAĞLAMINDA KOLLUĞUN TOPLANTI VE GÖSTERİ YÜRÜYÜŞÜ HAKKINA MÜDAHALESİ:

AIHM İÇTIHATLARI VE OMBUDSMAN KARARLARI ÇERÇEVSINDE BİR ANALIZZ

SAĞLAM, Fazıl (1982). Temel Hak ve Hürriyetlerin Sınırlandırılmasının Özü, A.Ü.S.B.F. Yayınları, Ankara.

ŞİRIN, Tolga (2013). 30 Soruda Toplantı ve Gösteri Yürüyüşü Hakkı, 12 Levha Yayınları, İstanbul.

TAN, Turgut, Şeref Gözübüyük (2010). İdare Hukuku Genel Esaslar Cilt 1, Seçkin Yayınları, Ankara.

TANYAR, Ziya Çağa (2011). Avrupa İnsan Hakları Mahkemesi İçtihadında Toplantı ve Gösteri Yürüyüşü Hakkı, Ankara Üniversitesi Hukuk Fakültesi Dergisi, Cilt 60, Sayı 3.

YILDIRIM, Ramazan, Yasin, Kaman, Özdemir, Üstün, Okay Tekinsoy (2013). İdare Hukuku, XII Levha Yayınları, İstanbul.

\section{Kararlar}

Anayasa Mahkemesi Karar1, Esas No: 2004/90, Karar No: 2008/78, Karar Tarihi: 11/03/2008.

Aşıcı ve Diğerleri/Türkiye Davası, Başvuru No: 17561/04, Karar Tarihi: 15/06/2010. 7

Serkan Yılmaz ve Diğerleri/Türkiye Davası, Başvuru No: 25499/04, Karar Tarihi: $13 / 10 / 2009$.

Turan Biçer /Türkiye Davas1, Başvuru No: 3224/03, Karar Tarihi: 30/11/2010.

Akgöl ve Göl/ Türkiye Davası, Başvuru No: 28495/06 ve 28516/06, Karar Tarihi: 17/05/2011.

Açık ve Diğerleri/ Türkiye, Başvuru No: 31451/03, Karar Tarihi: 13/01/2009.

Biçici/Türkiye Davası, Başvuru No: 30357/05, Karar Tarihi: 27/05/2010.

Çetinkaya/Türkiye Davası, Başvuru No: 75569/01, Karar Tarihi: 27/06/2006.

Demir ve Baykara/Türkiye Davası, Başvuru No: 34503/97, Karar Tarihi: 12/11/2008.

Gülizar Tuncer/Türkiye Davası, Başvuru No: 12903/02, Karar Tarihi: 08/02/2011.

Nurettin Aldemir ve Diğerleri/Türkiye Davası, Başvuru No: 32124/02, Karar Tarihi: $18 / 12 / 2007$.

Gün ve Diğerleri/Türkiye Davas1, Başvuru No: 8029/07, Karar Tarihi: 18/06/2013.

İzci/Türkiye Davas1, Başvuru No: 42606/05, Karar Tarihi: 23/07/2013.

Oya Ataman/Türkiye Davası, Başvuru No: 74552/01, Karar Tarihi: 05/12/2006.

Pekaslan ve Diğerleri/Türkiye Davası, Başvuru No: 4572/06, Karar Tarihi: 20/03/2012.

Saya ve Diğerleri/Türkiye Davası, Başvuru No: 4327/02, Karar Tarihi: 07/10/2008.

Kamu Denetçiliği Kurumu Tavsiye Kararı, Karar No: 2013/ 90, Karar Tarihi: 03/12/2013.

Kamu Denetçiliği Kurumu Tavsiye Kararı, Karar No: 2013/ 69, Karar Tarihi: 05/11/2013.

Kamu Denetçiliği Kurumu Tavsiye Kararı, Karar No: 2013/ 33, Karar Tarihi: 08/10/2013. 